\title{
Evidence of fibrinogen as a target of citrullination in IgM rheumatoid factor-positive polyarticular juvenile idiopathic arthritis
}

\author{
Brooke E Gilliam*, Melinda R Reed, Anil K Chauhan, Amanda Dehlendorf, Peri H Pepmueller, Terry L Moore \\ From 2011 Pediatric Rheumatology Symposium sponsored by the American College of Rheumatology \\ Miami, FL, USA. 2-5 June 2011
}

\section{Purpose}

The role of anti-cyclic citrullinated peptide (anti-CCP) antibodies in juvenile idiopathic arthritis (JIA) has become better understood; however, the identity of the target proteins of this modification remains elusive. We evaluated serum from patients with various subtypes of JIA to investigate the presence of anti-citrullinated fibrinogen and anti-citrullinated $\alpha$-enolase antibodies, and their association with rheumatoid factor (RF) and antiCCP antibodies.

\section{Methods}

Sera were obtained from 96 JIA patients, 19 systemic lupus erythematosus (SLE) patients, and 10 healthy children. All sera were measured for antibodies against citrullinated and native fibrinogen and $\alpha$-enolase by enzyme-linked immunosorbent assay. All results were correlated with clinical and laboratory parameters.

\section{Results}

Thirty-one (32\%) JIA patients demonstrated reactivity to citrullinated fibrinogen and $9(9 \%)$ to citrullinated $\alpha$-enolase. Reactivity to citrullinated fibrinogen and $\alpha$-enolase was predominantly found in IgM RF-positive polyarthritis patients ( $81 \%$ and $18 \%$, respectively). Anti-citrullinated fibrinogen antibodies were significantly elevated in JIA patients when compared to the healthy and SLE control groups $(\mathrm{p}<0.05)$. Antibody reactivity patterns showed that the largest group of JIA patients reacted only with fibrinogen $(17 \%)$. Ninety-three percent of JIA patients positive for IgG anti-CCP antibodies also reacted with citrullinated fibrinogen, making up 10\% of the JIA population. Anticitrullinated fibrinogen antibodies correlated significantly with IgG and IgA anti-CCP antibodies and IgA and IgM RF $(p<0.05)$. Significantly elevated levels of IgG, IgM, and IgA anti-CCP antibodies, and IgA and IgM RF were noted in JIA patients who were also positive for anti-citrullinated fibrinogen antibodies. IgM RF and anti-citrullinated fibrinogen antibodies demonstrated the highest sensitivity for IgM RF-positive polyarthritis $(100 \%$ and $81.3 \%$, respectively) and JIA overall (43.4\% and 32.3\% respectively). IgG and IgA anti-CCP antibodies and anti-citrullinated fibrinogen antibodies exhibited the highest specificity for JIA ( $96.6 \%, 86.2 \%$, and $86.2 \%$, respectively).

\section{Conclusion}

Of the antibodies measured in this study, anti-citrullinated fibrinogen antibodies showed the strongest association with JIA when compared to healthy and SLE control groups. Additionally, anti-citrullinated fibrinogen antibodies demonstrated high sensitivity and specificity for IgM RF-positive polyarthritis patients, along with IgG anti-CCP antibodies and IgM RF. Our data would suggest that measuring anti-citrullinated fibrinogen antibodies, in addition to anti-CCP antibody isotypes and IgM RF, may be beneficial in identifying patients that will develop more aggressive disease. For the first time, we have identified fibrinogen as a potential target for citrullination in JIA, particularly in patients with IgM RF-positive polyarticular JIA.

\section{Disclosure}

Brooke E. Gilliam: None; Melinda R. Reed: None; Anil K. Chauhan: None; Amanda Dehlendorf: None; Peri H. Pepmueller: None; Terry L. Moore: None. 
doi:10.1186/1546-0096-10-S1-A119

Cite this article as: Gilliam et al.: Evidence of fibrinogen as a target of citrullination in IgM rheumatoid factor-positive polyarticular juvenile idiopathic arthritis. Pediatric Rheumatology 2012 10(Suppl 1):A119.

Submit your next manuscript to BioMed Central and take full advantage of:

- Convenient online submission

- Thorough peer review

- No space constraints or color figure charges

- Immediate publication on acceptance

- Inclusion in PubMed, CAS, Scopus and Google Scholar

- Research which is freely available for redistribution

Submit your manuscript at www.biomedcentral.com/submit
C Biomed Central 